\title{
Technetium-99m Ceftizoxime Kit Preparation
}

\author{
Simone Odília Fernandes Diniz ${ }^{1 *}$, Cristiano Ferrari Siqueira ${ }^{1}$, David Lee Nelson ${ }^{1}$, Josep \\ Martin-Comin ${ }^{2}$ and Valbert Nascimento Cardoso ${ }^{1}$ \\ ${ }^{I}$ Faculdade de Farmácia; Universidade Federal de Minas Gerais; simone@farmacia.ufmg.br; Belo Horizonte - MG \\ - Brasil. ${ }^{2}$ Universitaria de Bellvitge; Barcelona - España
}

\begin{abstract}
The aim of this work was to prepare a kit of ${ }^{99 m}$ Tc-ceftizoxime $\left({ }^{99 m} T c\right.$-CFT), with stability and biological activity preserved, able to identify a septic focus (E. coli) in the experimental infection model in rats. The preparation of the CFT kit involved the use of lyophilized solutions containing the antibiotic ceftizoxime and the sodium dithionite reducing agent $(6.0 \mathrm{mg} / \mathrm{mL})$. After lyophilization, the kit was reconstituted with $1.0 \mathrm{~mL}$ of sodium ${ }^{99 m}$ Tcpertechnetate solution $\left(\mathrm{Na}^{99 m} \mathrm{TcO}_{4}\right.$-) with an activity of $370 \mathrm{MBq}$. The solution was boiled for 10 min and filtered through a cellulose ester filter. The labeling efficiency was on the order of 92\%, remaining stable for six hours and the kit remained stable for two months. The biological activity of the ${ }^{99 m}$ Tc-CFT was evaluated by diffusion in agar impregnated with E.coli and S. aureus. Seven Wistar rats, weighing from 200 to $250 \mathrm{~g}$, were used for the development of the septic focus. After 24 hours from the induction of the infectious site (E.coli), the animals were anesthetized and $0.1 \mathrm{~mL}$ of ${ }^{99 m} \mathrm{Tc}-\mathrm{CFT}(37 \mathrm{MBq})$ was injected into the tail veins of the animals. The images were obtained with a gamma camera one, two and six hours after injection and the regions of interest (ROIs) were calculated. The diameters of the inhibition halos for ${ }^{99 m}$ Tc-CFT were $27.16 \pm 0.23$ and $27.17 \pm 0.20$ for S.aureus and E.coli, respectively, while those for the unlabeled CFT were $30.4 \pm 0.33$ and $29.43 \pm 0.26$, respectively. The results for the biodistribution of ${ }^{99 m}$ Tc-CFT in infected animals furnished a ratio of $1.97 \pm 0.31,2.10 \pm 0.42$ and $2.01 \pm 0.42$ for cpm-target/cpm-no target for the one, two and six-hour periods, respectively. The images showed a clear uptake of labeled antibiotic $\left({ }^{99 m} T c-C F T\right)$ by the infectious site during the experiment. The results attest to the viability of producing a kit with ${ }^{99 m}$ technetium-labeled ceftizoxime for the investigation of infectious processes.
\end{abstract}

Key words: Tc-99m Ceftizoxime, infection, gamma scintigraphy

\section{INTRODUCTION}

Inflammation is one of the organism's principal defensive reactions. It is a reaction of the vascular connective tissue to an aggressive agent characterized by the movement of liquid and cells from the blood stream to the interstices, while an infection is defined as the invasion and multiplication of microorganisms. Although its causes such as traumatism, microorganisms, chemical agents and heat vary considerably, the mechanisms for the appearance of inflammations are similar (Brasileiro filho, 2000; Mitchell and Cotran, 2003).

The conventional imaging techniques such as radiology, computerized tomography (CT) and nuclear magnetic resonance (NMR) are not capable of differentiating between inflammatory and infectious processes. In addition, these techniques are based on important anatomic alterations and the possibility of a precocious diagnosis is limited (Becker, 1995).

\footnotetext{
* Author for correspondence
} 
Contrary to conventional imaging techniques, imaging scintilography is based on physiological and biochemical alterations resulting from inflammatory and infectious processes. The radiolabeled leucocytes can be considered gold standard for the identification of inflammatory foci in the intestine and bone tissue (Cardoso et al., 2002; Martin-Comin et al., 2002) However, the need to handle potentially contaminated blood can lead to the transmission of virus such as HIV and hepatitis B and C. In addition, the preparation of this radiopharmaceutical is laborious and requires specialized equipment, taking approximately three hours. The labeled leucocytes are not able to distinguish aseptic from septic inflammations. The development of new radiopharmaceuticals that do not require the manipulation of blood, able of to differentiate between inflammatory and infectious processes with high sensibility and specificity has been the object of recent research. Therefore, other preparations such as ${ }^{99 \mathrm{~m}} \mathrm{Tc}$-nanocolloid, ${ }^{67} \mathrm{Ga}-$ citrate and ${ }^{99 \mathrm{~m}} \mathrm{Tc}$ or ${ }^{111} \mathrm{In}$-labeled human polyclonal immunoglobulin are currently being tested (Weiner, 1990; Buscombe et al., 1991; McAfee et al., 1991 Becker, 1995). However, none of the preparations is capable of distinguishing between infections and inflammatory lesions in a clinically useful manner.

A new proposal is based on the use of radiolabeled antibiotics. Currently, the use of these antibiotics is restricted to some research centers in Europe. Recently, a new radiopharmaceutical, ${ }^{99 \mathrm{~m}} \mathrm{Tc}$ ciprofloxacin (Infecton), has been developed. Infecton is a wide spectrum fluoroquinolone having a biological half-life of 3.5 to 4.5 horas, $70 \%$ of the injected dose being eliminated within 24 hours. The microbiological activity is mediated by inactivation of bacterial DNA gyrase (Vinjamuri et al., 1996; Britton et al., 1997; Hall et al., 1998).

Barreto et al. (2000) labeled a third generation cephalosporin, ceftizoxime, with ${ }^{99 \mathrm{~m}} \mathrm{Tc}$ $\left({ }^{99 \mathrm{~m}} \mathrm{Tc}-\mathrm{CFT}\right)$. CFT has a wide spectrum of activity to the betalactamases, binds to the bacterial wall, inhibits the synthesis of peptidoglycan and therefore inhibits the synthesis of bacterial wall, which drives to bacterial death. This antibiotic is sensitive to light, soluble in water and stable at high temperatures. After administration, the excretion occurs by glomerular filtration and tubular secretion. It has a half-life of 1.7 hours, being almost totally eliminated $(100 \%)$ within 24 hours (Tavares, 2002). The objective of the present work was the development of a biologically active ${ }^{99 \mathrm{~m}}$ Tc-ceftizoxime kit capable of identifying infectious foci in an experimental model of infection in rats.

\section{MATERIAL AND METHODS}

\section{Preparation of the kit}

The kit was produced using a commercial preparation of Ceftizoxime (Cefizox® 1000 IVSmith Kline and French, S.A.) and a solution of sodium dithionite $\left(\mathrm{Na}_{2} \mathrm{~S}_{2} \mathrm{O}_{4}-6.0 \mathrm{mg} / \mathrm{mL}\right)$. The solution was filtered through a cellulose ester filter $(0.22 \mu \mathrm{m})$. Aliquots of $1.0 \mathrm{~mL}$ were transferred to glass vials, frozen in liquid nitrogen and lyophilized for 18 hours. After that, some vials were sealed under nitrogen and others under vacuum.

\section{Labeling with ${ }^{99 \mathrm{~m}} \mathbf{T c}$}

The kit was reconstituted with $1.0 \mathrm{~mL}$ of sodium ${ }^{99 \mathrm{~m}}$ Tc-pertechnetate solution $\left(\mathrm{Na}^{99 \mathrm{~m}} \mathrm{TcO}_{4}\right)$ having an activity of $370 \mathrm{MBq}$. The solution was boiled for ten min and cooled in running water for five min. The solution was filtered through a cellulose ester filter $(0.22 \mu \mathrm{m})$ to remove radiochemical contaminants, mainly the ${ }^{99 \mathrm{~m}} \mathrm{TcO}_{2}$, and collected in a vial under vacuum.

\section{Radiochemical purity}

The ${ }^{99 \mathrm{~m}}$ Tc-ceftizoxime was checked for radiochemical purity by ITLC (instantaneous thin layer chromatography) with silica gel (SG).

The ${ }^{99 \mathrm{~m}}$ Tc-ceftizoxime $(3 \mu \mathrm{L})$ was applied to $1 \mathrm{x}$ $10 \mathrm{~cm}$ ITLC-SG/MEK plates and ITLC$\mathrm{SG} / 0.9 \% \mathrm{NaCl}$ to determine the amount of free ${ }^{99} \mathrm{TcO}_{4}^{-}$and ${ }^{99 \mathrm{~m}} \mathrm{TcO}_{2}$, respectively, by ascending chromatography.

The radiochemical purity (RP) was determined from the following equation:

$$
\% \mathbf{R P}=\frac{\mathrm{cpm} \text { of }{ }^{99 \mathrm{~m}} \mathrm{Tc}-\mathrm{CFT}}{\sum \mathrm{cpm}\left({ }^{99 \mathrm{~m}} \mathrm{TcO}_{2}+{ }^{99 \mathrm{~m}} \mathrm{TcO}_{4}{ }^{-}+{ }^{99 \mathrm{~m}} \mathrm{Tc}-\mathrm{CFT}\right)}
$$

\section{Stability of ${ }^{99 \mathrm{~m}}$ Tc-ceftizoxime}

After labeling ceftizoxime with ${ }^{99 \mathrm{~m}} \mathrm{Tc}\left({ }^{99 \mathrm{~m}} \mathrm{Tc}-\right.$ CFT), it was left at room temperature for two, four and six hours. The labeling stability of ${ }^{99 \mathrm{~m}} \mathrm{Tc}-\mathrm{CFT}$ was evaluated by determination of the 
radiochemical purity after each of these periods $(n=6)$.

\section{Stability of the kit for labeling Tc-99m ceftizoxime}

The stability of the preparation kit was determined at 1, 7, 14, 30 and 60 days after storage: a) freezer at $-70{ }^{\circ} \mathrm{C}$, with and without nitrogen atmosphere; b) freezer at $-25{ }^{\circ} \mathrm{C}$, with and without nitrogen atmosphere $(n=6)$.

\section{In vitro tests for antimicrobial activity}

The antimicrobial activity of the antibiotic was determined by the disk diffusion method in agar plates impregnated with Staphylococcus aureus ATCC 6538-P (Gram-positive) and Escherichia coli - ATCC 8739 (Gram-negative). Three disks were used with each Petri dish:

Disk 1 - $25 \mu \mathrm{g} / 10 \mu \mathrm{L}$ of ${ }^{99 \mathrm{~m}}$ Tc-ceftizoxime;

Disk 2 - $25 \mu \mathrm{g} / 10 \mu \mathrm{L}$ of unlabeled ceftizoxime;

Disk 3 - $25 \mu \mathrm{g} / 10 \mu \mathrm{L}$ of ceftizoxime plus labeling reagents without ${ }^{99 \mathrm{~m}}$ Technetium.

Biological activity was evaluated by measuring the diameter of the inhibition halos $(\mathrm{mm})$ obtained on the plates after 24 hours of incubation at $37{ }^{\circ} \mathrm{C}$.

\section{Experimental Infection Model}

Wistar rats, 200-250 g, were anesthetized by intraperitoneal administration of a mixture of Rompun ${ }^{\circledR}(12.5 \mathrm{mg} / \mathrm{Kg})$ and Dopalen ${ }^{\circledR}(1.25$ $\mathrm{mg} / \mathrm{Kg}$ ), and the infectious process was induced by direct injection of Escherichia coli $(25 \mu \mathrm{L})$ containing approximately $10^{8}$ colony forming units $(\mathrm{CFU} / \mathrm{mL})$ into the left thigh muscle (target) of the animals $(n=7)$. A sterile saline solution $(25 \mu \mathrm{L})$ was injected into the right thigh (no target) to serve as a control.

\section{Scintilographic images of the animals}

a) Biodistribution of ${ }^{99 \mathrm{~m}} \mathrm{TcO}_{4},{ }^{99} \mathrm{TcO}_{2}$ and ${ }^{99 m}$ Technetium-CFT

The biodistribution of ${ }^{99} \mathrm{TcO}_{4},{ }^{99} \mathrm{TcO}_{2}$ and ${ }^{99 \mathrm{~m}} \mathrm{Tc}-\mathrm{CFT}$ was evaluated in Wistar rats (body mass: $200-250 \mathrm{~g}$ ). Aliquots of each preparation (37
$\mathrm{MBq}$ ) were injected into the tail vein. One hour after injection, the animals were anesthetized by intra-peritoneal administration of Rompun ${ }^{\circledR}$ $(12.5 \mathrm{mg} / \mathrm{Kg})$ and Dopalen ${ }^{\circledR}(1.25 \mathrm{mg} / \mathrm{Kg})$, and images were obtained on a gamma camera, Vertex Plus.

\section{b) Foci of inflammation/infection}

The animals were anesthetized with Rompum ${ }^{\circledR} / \operatorname{Ketamin}{ }^{\circledR}(1.0 \mathrm{~g}$ and $0.25 \mathrm{~g} / \mathrm{kg}) 24$ hours after the induction of the infectious focus, and $0.1 \mathrm{~mL}$ of ${ }^{99 \mathrm{~m}}$ Tc-ceftizoxima (37 MBq) was injected into the tail veins of the animals. The planar static images of the anterior position were acquired one, two and six hours after injection using the gamma camera. The regions of interest (ROIs) were drawn around infectious focus left thigh and a comparable zone in the contralateral normal right thigh (control). The target-to-no target ratio was calculated using the following equation:

$$
\text { target-to/no target }=\frac{\text { Counts left thigh }}{\text { Counts right thigh (control) }}
$$

\section{Statistical analyses}

The results were analyzed by the Student $t$ test for independent samples. The differences were considered statistically significant for values of $\mathrm{p}=0.05$.

\section{RESULTS}

The results for the radiochemical purity of the ${ }^{99 \mathrm{~m}} \mathrm{Tc}-\mathrm{CFT}$, with and without a nitrogen atmosphere, stored in a freezer at $-70{ }^{\circ} \mathrm{C}$ and $25{ }^{\circ} \mathrm{C}$ for zero, one, two and six hours after labeling, are shown in Table 1. The data did not show a statistically significant difference for the times investigated.

Table 1 - Stability of Tc-99m Ceftizoxime

\begin{tabular}{c|c|c|c|c}
\hline \multirow{2}{*}{ Time after labelling (h) } & \multicolumn{4}{|c}{ Radiochemical purity (\%) } \\
\cline { 2 - 5 } & $\mathrm{N} 2\left(-70^{0}\right)$ & w/o N2 $\left(-70^{0}\right)$ & $\mathrm{N} 2\left(-25^{0}\right)$ & w/o N2 $\left(-25^{0}\right)$ \\
\hline 0 & $94.60 \pm 1.82$ & $94.53 \pm 1.77$ & $92.85 \pm 1.66$ & $92.25 \pm 1.88$ \\
\hline 1 & $93.10 \pm 1.55$ & $91.89 \pm 1.88$ & $92.10 \pm 1.99$ & $92.85 \pm 1.37$ \\
\hline 2 & $92.00 \pm 1.78$ & $95.62 \pm 2.58$ & $94.69 \pm 1.87$ & $94.52 \pm 2.21$ \\
\hline 6 & $92.43 \pm 1.69$ & $93.55 \pm 1.79$ & $91.45 \pm 1.45$ & $93.19 \pm 2.31$ \\
\hline
\end{tabular}

Values expressed as the mean $\pm \mathrm{sd}, \mathrm{n}=6(\mathrm{p} \geq 0.05)$. 
The kit for labeling of ceftizoxime with ${ }^{99 \mathrm{~m}}$ Technetium is stable for at least two months after preparation (Table 2). The results also did not show significant differences between the times investigated for the treatments employed.

The diameters of the inhibition halos for $S$. aureus were $27.16 \pm 0.23 ; 30.4 \pm 0.33$ and $28.52 \pm 0.61 \mathrm{~mm}$ and for E.coli, $27.17 \pm 0.20 ; 29.43 \pm 0.26$ and $28.22 \pm 0.13 \mathrm{~mm}$ for ${ }^{99 \mathrm{~m}} \mathrm{Tc}-\mathrm{CFT}$, unlabeled CFT and CFT + reagents, respectively (Figs. 1 and 2).
The biodistribution typical of ${ }^{99}{ }^{9} \mathrm{TcO}_{4}^{-}$with radioactivity uptake by thyroid, stomach and bladder can be seen in Fig. 3a. The ${ }^{99 \mathrm{~m}} \mathrm{Tc}$-CFT biodistribution showed a high uptake by the kidney, indicating a renal excretion (Fig. 3b), while the ${ }^{99 \mathrm{~m}} \mathrm{TcO}_{2}$ was uptake by the liver and spleen (Fig. 3c).

Table 2 - Stability of the kit for labeling of Tc-99m Ceftizoxime

\begin{tabular}{c|c|c|c|c}
\hline \multirow{2}{*}{\begin{tabular}{l} 
Days after $\begin{array}{l}\text { Radiochemical purity (\%) } \\
\text { preparation }\end{array}$ \\
\cline { 2 - 5 }
\end{tabular}} & $\mathrm{N} 2\left(-70^{0}\right)$ & w/o N2 $\left(-70^{0}\right)$ & $\mathrm{N} 2\left(-25^{0}\right)$ & $\mathrm{w} / \mathrm{o} \mathrm{N} 2\left(-25^{0}\right)$ \\
\hline 0 & $94.60 \pm 1.99$ & $94.53 \pm 1.77$ & $92.85 \pm 1.66$ & $92.25 \pm 1.88$ \\
\hline 7 & $92.13 \pm 1.00$ & $91.4 \pm 1.37$ & $91.67 \pm 1.40$ & $93.67 \pm 1.89$ \\
\hline 14 & $92.14 \pm 1.33$ & $91.55 \pm 1.56$ & $91.53 \pm 1.22$ & $91.45 \pm 1.34$ \\
\hline 30 & $90.00 \pm 2.33$ & $90.10 \pm 2.32$ & $94.11 \pm 1.89$ & $90.15 \pm 2.59$ \\
\hline 60 & $94.86 \pm 1.83$ & $94.75 \pm 2.89$ & $94.00 \pm 1.90$ & $91.63 \pm 1.99$ \\
\hline$\overline{\mathrm{X}} \pm \mathrm{sd}$ & $92.74 \pm 2.01$ & $92.46 \pm 2.06$ & $93.00 \pm 1.46$ & $91.83 \pm 1.28$ \\
\hline
\end{tabular}

Values expressed as the mean $\pm \mathrm{sd}, \mathrm{n}=6(\mathrm{p} \geq 0.05)$.

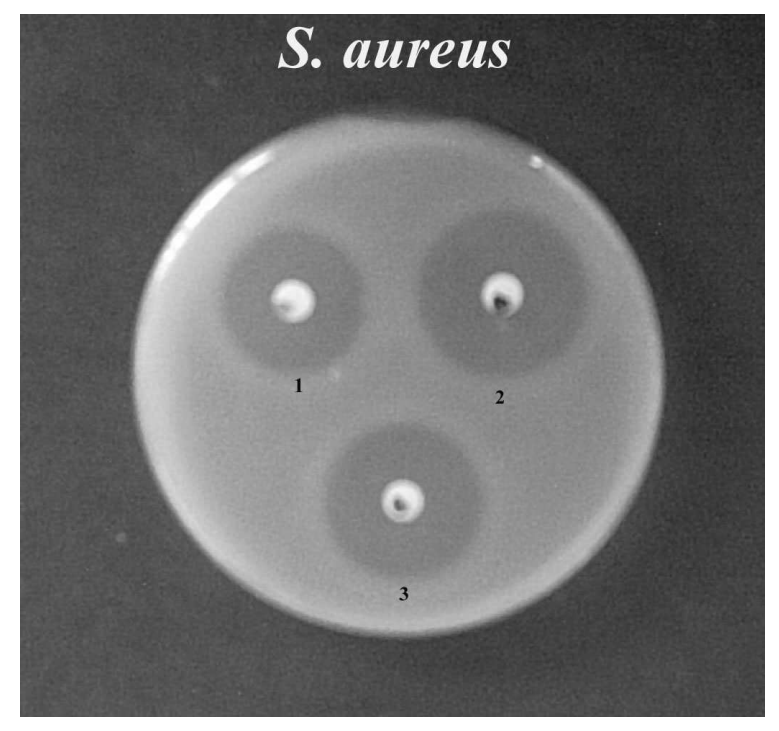

Figure 1 - Inhibition halos in agar plates impregnated with $S$. aureus - ATCC 6538$\mathrm{P}$

$$
\begin{aligned}
& 1-{ }^{99 \mathrm{~m}} \text { Tc-CFT 2-unlabeled CFT 3-CFT } \\
& + \text { reagents }
\end{aligned}
$$

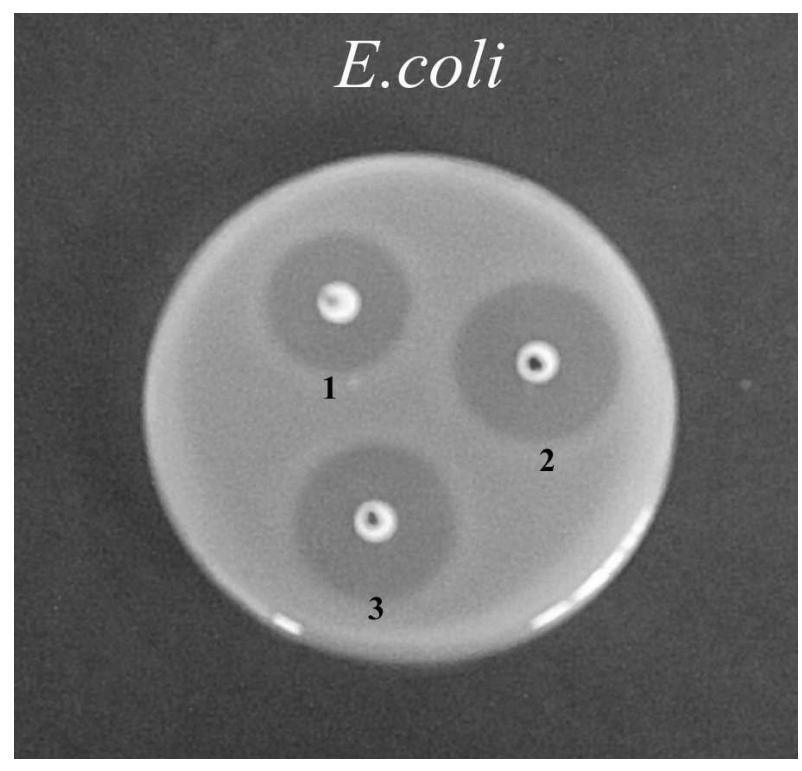

Figure 2 - Inhibition halos in agar plates impregnated with E. coli - ATCC 8739

1- ${ }^{99 \mathrm{~m}} \mathrm{Tc}-\mathrm{CFT}$ 2-unlabeled CFT $3-\mathrm{CFT}+$ reagents 

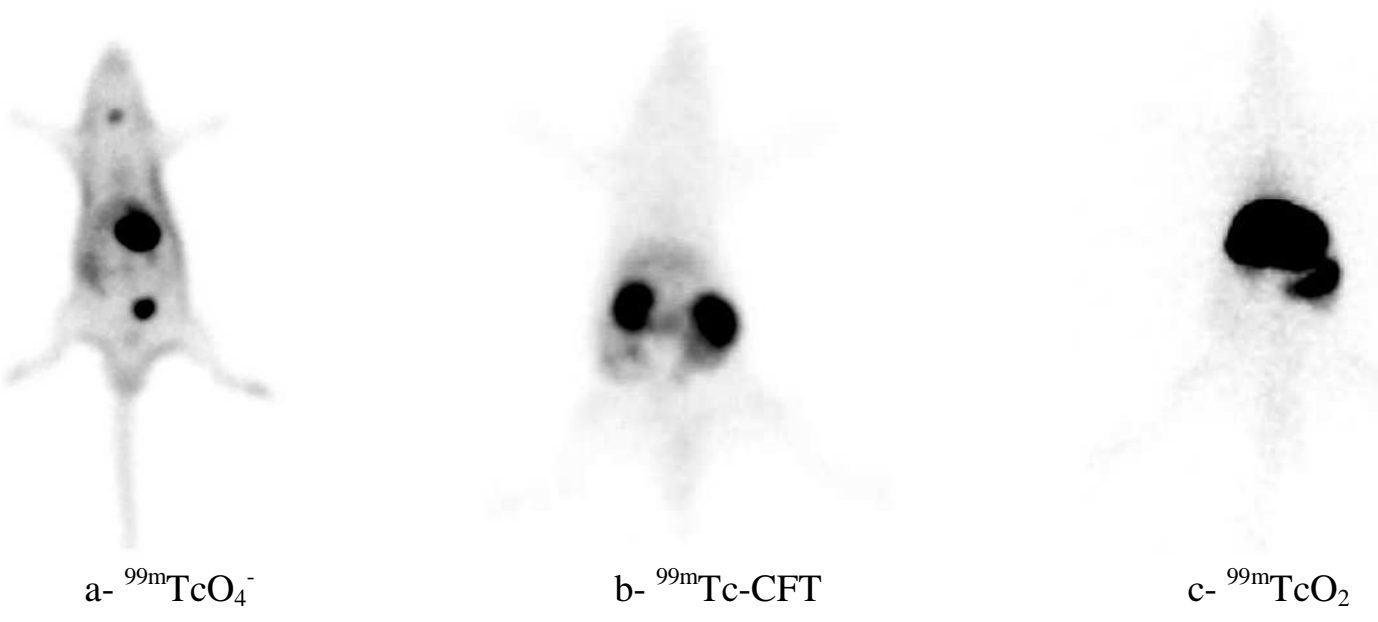

Figure 3 - Biodistribution of ${ }^{99 m}$ Technetium-free $\left({ }^{99} \mathrm{TcO}_{4}{ }^{-}\right)$, hydrolyzed ${ }^{99 \mathrm{~m}}$ Technetium $\left({ }^{99 \mathrm{~m}} \mathrm{TcO}_{2}\right)$ and Tc-99m Ceftizoxime (CFT) one hour after injection.

Ratios of $1.97 \pm 0.31,2.10 \pm 0.42$ and $2.01 \pm 0.42$ for the cpm of the left thigh to the cpm of the right thigh were observed for the one, two and six-hour periods, respectively (Table 3 ). These ratios show that there was a significant uptake of ${ }^{99 \mathrm{~m}} \mathrm{Tc}$ ceftizoxime by the infectious site in the left thigh. The data suggest that Tc-99m Ceftizoxime remained at the infectious focus during the whole experiment, there being no statistically significant difference in the ratios during the period studied.

As can be seen in Figs. 4A, B and C, there was a greater degree of ${ }^{99 \mathrm{~m}} \mathrm{Tc}-\mathrm{CFT}$ uptake by the infectious site in the left thigh (arrow) than in the right thigh (control) at one, two and six hours after administration. The images show the uptake of ${ }^{99 \mathrm{~m}} \mathrm{Tc}-\mathrm{CFT}$ until six hours after injection, suggesting a specific uptake by the infectious site.

Table 3 - Ratio left thigh (target) / right thigh (no target) in the experimental infection model.

\begin{tabular}{c|c|c|c}
\hline Experiment & 1 hour & 2 hour & 6 hour \\
\hline 1 & 1.64 & 1.46 & 2.53 \\
\hline 2 & 1.88 & 2.70 & 1.79 \\
\hline 3 & 2.25 & 1.96 & 1.86 \\
\hline 4 & 1.77 & 1.91 & 1.82 \\
\hline 5 & 1.66 & 1.92 & 2.06 \\
\hline 7 & 2.17 & 2.25 & 2.84 \\
\hline$X \pm s d$ & 2.45 & 2.51 & $2.01 \pm 0.42$ \\
\hline
\end{tabular}

Values expressed as the mean $\pm \mathrm{sd}, \mathrm{n}=7(\mathrm{p} \geq 0.05)$.

\section{DISCUSSION}

Although the radiolabeled leucocytes are considered to be a gold standard, this diagnostic agent does not differentiate between inflammation and infection (Sampson, 1996). Recent studies have demonstrated the possibility of utilizing radiolabeled antibiotics for differencial diagnostic of inflammatory and infectious processes (Sonmezoglu et al., 2001; Yapar et al., 2001).
The antibiotic that is most widely utilized is a fluorquinolone called Infecton. However, the results obtained have been contradictory with low reproducibility. This fact has generated a certain resistance on the part of the scientific community in accepting it as a reliable diagnostic agent. It may be because some workers have related a non-specific uptake of ${ }^{99 \mathrm{~m}} \mathrm{Tc}$-Infecton by inflammatory foci that have been proven to be aseptic (Larikka et al., 2002a; Larikka et al., 2002b). The authors suggest that, 
since ciprofloxacine has a low molecular weight $(\mathrm{MW}=331.3)$, low degree of interaction with plasmatic protein $(20-40 \%)$ and a biological half-life of 4.5 hours, it would interact with a variety of factors before interacting with bacteria. In this way, the researchers justified the non-specific uptake observed in images after one and four hours.

On the other hand, ceftizoxime (CFT) has a halflife of 1.7 hours, being almost totally eliminated within 24 hours after administration. As opposed to Infecton, ceftizoxime is more rapidly depurated from the organism, thus diminishing the circulating pool and favoring the specific capture by the infectious site over the nonspecific. Therefore, considering the criteria for obtaining an ideal radiopharmaceutical, ceftizoxime fits the criteria better. The purpose of the present work was the production of a kit with ceftizoxime in condition to be labeled with ${ }^{99 \mathrm{~m}}$ Technetium.

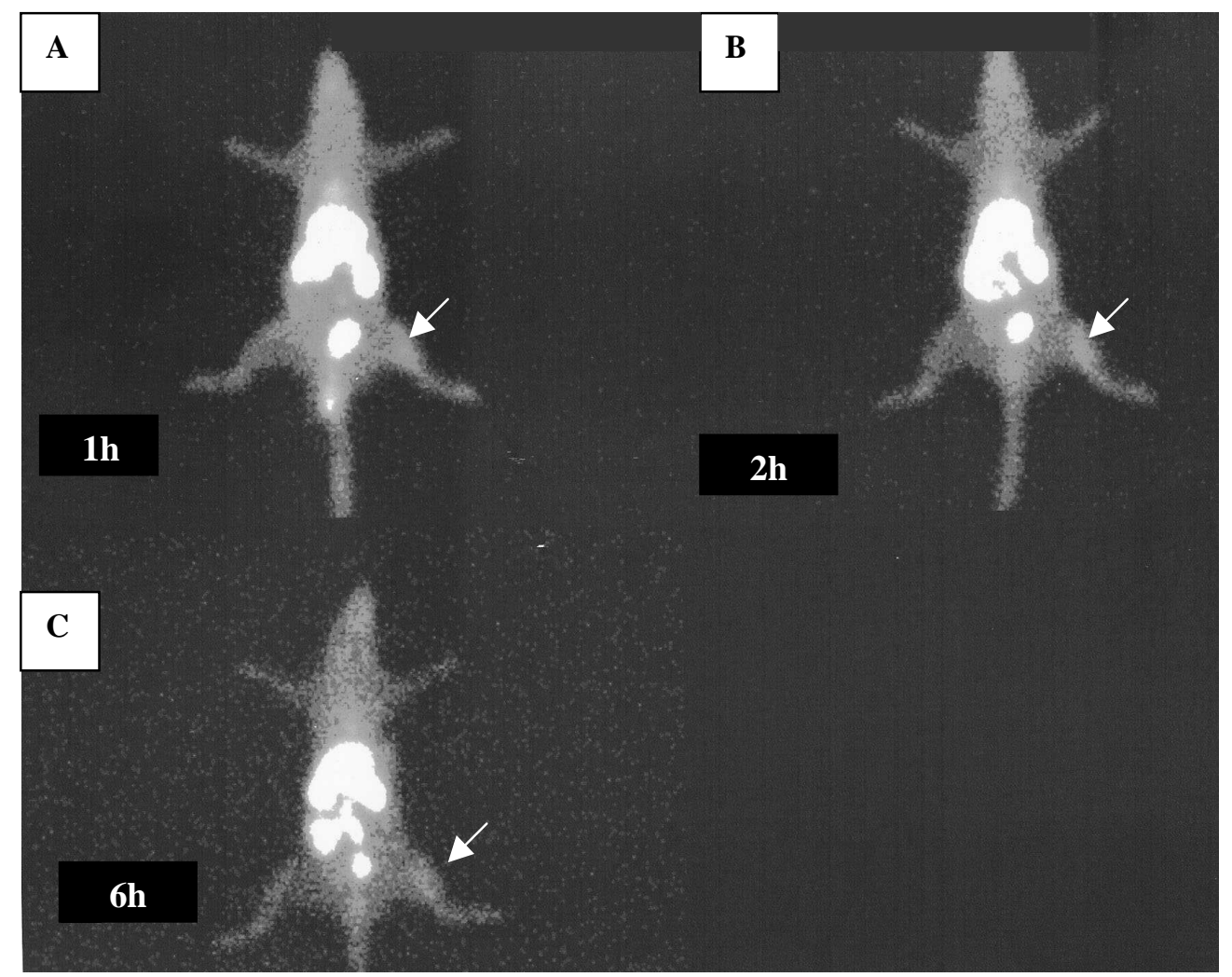

Figure $4-{ }^{99 \mathrm{~m}} \mathrm{Tc}-\mathrm{CFT}$ biodistribution at one, two and six hours after injection.

The preparation of the CFT kit utilized a mixture of solutions containing the antibiotic ceftizoxime $(2.5 \mathrm{mg} / \mathrm{mL})$ and the reducing agent sodium dithionite $(6.0 \mathrm{mg} / \mathrm{mL})$ that was lyophi'ized for a period of 18 hours. Part of the material produced was stored under nitrogen atmosphere while the rest were maintained under vacuum.

The yield labeling of CFT with ${ }^{99 \mathrm{~m}}$ Technetium using a kit formulation furnished results equal or superior to $90 \%$. Barreto et al. (2000) obtained similar results varying from 90.5 to $95.8 \%$ using a solution of ceftizoxime prepared at the moment of labeling. The results obtained in this work demonstrated that the labeled product was stable for a period of six hours, regardless of the storage conditions. In addition, the cime and temperature of storage did not interfere with the labeling yield, showing that the kit preparation was stable for two months (Table 2).

One of the essential characteristics in the preparation of the CFT kit is the preservation of the biological activity. In vitro tests with Staphylococcus aureus and Escherichia coli cultures presented inhibition halos of $27.16 \pm 0.23$ 
and $27.17 \pm 0.20 \mathrm{~mm}$, respectively, for ${ }^{99 \mathrm{~m}} \mathrm{Tc}-\mathrm{CFT}$. This observation showed that the labeled antibiotic was capable of recognizing both gram negative and gram positive bacteria, suggesting that the antibiotiic preserved its broad spectrum of activity even after labeling. The inhibition halos using non- labelled ceftizoxime were $30.4 \pm 0.33$ and $29.43 \pm 0.26 \mathrm{~mm}$ for $S$. aureus and E.coli, respectively. Thus, there was a $10 \%$ reduction in the biological activity of ${ }^{99 \mathrm{~m}}$ Technetium-labeled ceftizoxime relative to that of the non-labeled ceftizoxime. Barreto et al. (2000) observed a reduction in the biological activity on the order of $17 \%$ utilizing an E.coli culture and ${ }^{99 \mathrm{~m}} \mathrm{Tc}-\mathrm{CFT}$. Considering only the data obtained for E.coli in the present study, it can be seen that the attenuation of the biological activity of ${ }^{99 \mathrm{~m}} \mathrm{Tc}$-CFT was $7.7 \%$, suggesting that the formulation of a kit may be contributing for an improved preservation of the biological activity.

When the images obtained with ${ }^{99 \mathrm{~m}} \mathrm{TcO} 4,{ }^{99 \mathrm{~m}} \mathrm{TcO} 2$ and ${ }^{99 \mathrm{~m}} \mathrm{Tc}-\mathrm{CFT}$ are compared, the results show image patterns completely distinct, indicating that there is a significant uptake of ${ }^{99 \mathrm{~m}} \mathrm{Tc}$-CFT by the kidneys one hour after administration. This observation suggests that there is a rapid depuration of the labeled product, a result that is in accord with its characteristics described in the literature. At the same time, these data indicate that the ${ }^{99 \mathrm{~m}} \mathrm{Tc}-\mathrm{CFT}$ is free of radiochemical impurities, suggesting, therefore, that an in vivo stability of the labeled antibiotic exists.

The results for the ${ }^{99 \mathrm{~m}} \mathrm{Tc}-\mathrm{CFT}$ biodistribution in an experimental model of infection demonstrated that there is a greater uptake of ${ }^{99 \mathrm{~m}} \mathrm{Tc}$-CFT by the infectious site in the left thigh than in the control thigh. A constant ratio of target/no target during the experiment was observed, indicating that the labeled antibiotic remained at the site of infection. The image obtained six hours after administration of ${ }^{99 \mathrm{~m}} \mathrm{Tc}$-CFT also exhibited the presence of the labeled drug at the site of infection, suggesting a specific bind between the ${ }^{99 \mathrm{~m}} \mathrm{Tc}-\mathrm{CFT}$ and the infectious agent. The hypothesis that the labeled product would be encountered at this site simply because of an increase in blood flow and an increase in the vascular permeability provoked by the inflammation resulting from the infectious process must be discarded since the uptake of ${ }^{99 \mathrm{~m}} \mathrm{Tc}-\mathrm{CFT}$ was present at the target site until six hours after administration. Benitez et al. (2002) showed that the uptake of ${ }^{99 \mathrm{~m}} \mathrm{Tc}-\mathrm{CFT}$ by an aseptic inflammatory site diminished progressively 1,2 , and 6 hours after injection.

The results obtained in this work attest to the viability of producing a kit containing ceftizoxime labeled with ${ }^{99 \mathrm{~m}}$ Technetium for the investigation of infectious processes. However, additional studies related to the storage conditions and the stability over periods greater than two months should be performed before the commercial production of a CFT Kit will be viable.

\section{ACKNOWLEDGEMENTS}

The authors thank FAPEMIG for the financial support and the ECOGRAF Núcleo de Diagnóstico Cardiovascular clinic for the acquisition of the images of the animals with the gamma camera.

\section{RESUMO}

O objetivo deste trabalho foi preparar um kit de Tc-99m Ceftizoxima ( $\left({ }^{99 \mathrm{~m}}\right.$ Tc-CFT), com estabilidade e atividade biológica preservadas, capaz de identificar um foco séptico (E.coli) em um modelo experimental de infecção em ratos. A preparação do kit de CFT baseou-se em uma mistura de soluções contendo o antibiótico ceftizoxima $(2,5 \mathrm{mg} / \mathrm{mL})$ e o agente redutor ditionito de sódio $(6,0 \mathrm{mg} / \mathrm{mL})$ que foram submetidos a um processo de liofilização. Após a liofilização, o kit foi reconstituído with $1,0 \mathrm{~mL}$ de solução de pertecnetato de sódio $\left(\mathrm{Na}^{99 \mathrm{~m}} \mathrm{TcO}_{4}{ }^{-}\right)$, contendo uma atividade de $370 \mathrm{MBq}$. Em seguida, a solução foi incubada, por $10 \mathrm{~min}$, em banho fervente $\left(100^{\circ} \mathrm{C}\right)$ e, posteriormente, foi resfriada em água corrente por $5 \mathrm{~min}$. A eficiência de marcação foi da ordem de $92 \%$ permanecendo estável por 6 horas e o kit permaneceu estável por 2 meses. A atividade biológica do ${ }^{99 \mathrm{~m}} \mathrm{Tc}-\mathrm{CFT}$ foi avaliada por difusão em ágar impregnado com E.coli e S. aureus. Foram utilizados 07 ratos Wistar, pesando entre 200 a $250 \mathrm{~g}$, para o desenvolvimento do foco séptico. Após 24 horas da indução do foco infeccioso (E.coli), os animais foram anestesiados e $0,1 \mathrm{~mL}$ da ${ }^{99 \mathrm{~m}} \mathrm{Tc}-\mathrm{CFT}$ (37 $\mathrm{MBq}$ ) foi injetado na veia da cauda dos animais. As imagens de 1, 2 e 6 horas após a injeção foram adquiridas em uma gama câmara e as regiões de interesse (ROIS) foram calculadas. Os valores obtidos dos diâmetros dos halos de inibição para 
${ }^{99 \mathrm{~m}}$ Tc-CFT foram $27,16 \pm 0,23$ e $27,17 \pm 0,20$ para $S$. aureus e E.coli, respectivamente, sendo que para CFT não marcada foram $30,4 \pm 0,33$ e $29,43 \pm 0,26$, respectivamente. Os resultados obtidos da biodistribuição da ${ }^{99 \mathrm{~m}} \mathrm{Tc}$-CFT nos animais com focos infecciosos mostraram uma relação alvo/não alvo de $1,97 \pm 0,31,2,10 \pm 0,42$ e $2,01 \pm 0,42$ para os tempos de 1,2 e 6 horas, respectivamente. As imagens obtidas mostraram nítida captação do antibiótico marcado $\left({ }^{99 \mathrm{~m}} \mathrm{Tc}-\mathrm{CFT}\right)$ pelo foco infeccioso ao longo do experimento. Os resultados obtidos neste trabalho atestam a viabilidade de produção de um kit da ceftizoxima marcada com ${ }^{99} \mathrm{~m}_{\text {tecnécio para investigações de processos }}$ infecciosos.

\section{REFERENCES}

Barreto, V.G.; Iglesias, F.; Roca, M.; Tubau, F.; MartinComin, J. (2000), Marcaje de ceftizoxime com ${ }^{99 \mathrm{~m}}$ Tc. Rev. Esp. Med. Nuclear, 19, 479-483.

Becker, W. (1995), The contribution of nuclear medicine to the patient with infection. Eur. J. Nucl. Med., 22, 1195-1211.

Benítez, A.; Barreto, V.G.; Roca, M.; Martin-Comin, J. (2002), The use of radiolabelled antibiotics to localise inflammation and infection. In-Nuclear Medicine in Tropical and Infectious Diseases. Braga, F. J.N. Kluwer Academic Publishers, Massachusetts, pp. 227-232.

Brasileiro Filho, G. (2000), In-Bogliolo Patologia. ed. 6. Pereira, F.E.L.; Bogliolo, L. Guanabara Koogan, Rio de Janeiro, pp. 112-147.

Britton, K.E.; Vinjamuri, S.; Hall, A.V.; Solanki, K.; Siraj, Q.H.; Bomanji, J.; Das, S. (1997), Clinical evaluation of technetium- ${ }^{99 \mathrm{~m}}$ infecton for the localization of bacterial infection. Eur. J. nucl. Med., 24, 553-556.

Buscombe, J.R.; Miller, R.F; Lui, D et al., (1991), Combined Gallium-67-citrate and ${ }^{99 \mathrm{~m}}$ Tc-human immunoglobulin imaging in human immunodeficiency virus-positive patients with fever of unknown origin. Nucl. Med. Commun, 12; 583592.

Cardoso, V.N; Plaza, P.; Roca, M., Armero, F.; MartinComin, J. (2002), Assessment of inflammatory bowel disease with two different ${ }^{99 \mathrm{~m}} \mathrm{Tc}$-Leucocytes labelling methods. Nucl. Med. Commun., 23, 715720.

Hall, A.V. (1998), Evaluation of the efficacy of ${ }^{99 m}$ TcInfecton, a novel agent for detecting sites of infection. J. Clin. Pathol., 51, 215-219.

Larikka, M.J.; Ahonen, A.K.; Niemelä, O.; Puronto, O.; Junila, J.A.; Hämäläinen, M.M.; Britton, K.E., Syrjälä, H.P. (2002a) Comparison of ${ }^{99 m} \mathrm{Tc}$ - ciprofloxacin, ${ }^{99 \mathrm{~m}} \mathrm{Tc}$ white blood cell and three-phase bone imaging in the diagnosis of hip prosthesis infections: improved diagnostic accuracy with extended imaging time. Nucl. Med. Commun., 23, 655-661.

Larikka, M.J.; Ahonen, A.K.; Niemelä, O.; Puronto, O.; Junila, J.A.; Hämäläinen, M.M.; Britton, K.E.; Syrjälä, H.P. (2002b), ${ }^{99 \mathrm{~m}}$ Tc-ciprofloxacin (Infecton) imaging in the diagnosis of knee prosthesis infections. Nucl Med. Commum., 23, 167-170.

Martin-Comin, J.; Cardoso, V.N.; Plaza, P. et al. (2002), Hank's balanced salt solution: an alternative resuspension medium to label autologous leukocytes. Experience in inflammatory bowel disease. Braz. arch. biol. technol., 45, 39-44.

McAfee, J.G.; Gagne, G.; Subramanian, G.; Schneider, R.F. (1991), The localization of indium-111leucocytes, gallium-67, polyclonal IgG and other radioactive agents in acute focal inflammatory lesions. J. Nucl. Med., 32, 2126-2131.

Mitchell, R.N. and Cotran, R.S. (2003), Acute and chronic inflammation. In-Robbins basic pathology. ed. 7. Kumar, V.; Cotran, R.S.; Robbins, S.L., Saunders, Philadelphia, pp. 53-59.

Sampson, C.B. (1996), Complications and difficulties in radiolabelling blood cells: A review. Nucl. Med. Commun., 17, 648-658.

Sonmezoglu, K.; Sonmezoglu, M.; Halac, M.; Akgün, I.; Türkmen, C.; Önsel, C.; Kanmaz, B.; Solanki, K.; Britton, K.E.; Uslu, I. (2001), Usefulness of ${ }^{99 m}$ TcCiprofloxacin (infecton) scan in diagnosis of chronic orthopedic infections: Comparative study with ${ }^{99 m}$ Tc-HMPAO leukocyte scintigraphy. J. Nucl. Med., 42, 567-574.

Tavares, W. (2002), Manual de antibióticos $e$ quimioterápicos antiinfecciosos. Atheneu, São Paulo.

Weiner, R. (1990), The role of transferring and other receptors in the mechanism of $\mathrm{Ga}^{67}$ localization. Int. J. Rad. Appl. Instrum. B., 17, 141-149.

Vinjamuri, S.H.; Hall, A.V.; Solanki, K.K. et al. (1996), Comparison of ${ }^{99 \mathrm{~m}}$ Tc-Infecton imaging with radiolabelled white-cell imaging in the evaluation of bacterial infection. Lancet., 347, 233-235.

Yapar, Z.; Kibar, M.; Yapar, A.F.; Togrul, E.; Kayaselçuk, U.; Sarpel, Y. (2001), The efficacy of ${ }^{99} \mathrm{~m}$ technetium ciprofloxacin (Infecton) imaging in suspected orthopaedic infection: a comparison with sequential bone/gallium imaging. Eur. J. Nucl. Med. 28, 822-830.

Received: July 04, 2005;

Revised: July 14, 2005; Accepted: August 01, 2005. 